\title{
Invasion of the Eastern Red Cedar
}

\section{This juniper is rapidly claiming Oklahoma rangelands. Here's an update on the economic and environmental impact, and a review of control strategies.}

\author{
By Zeb Barth, Representing the Oklahoma SRM Section
}

$\mathrm{P}$ icture the life of an ordinary European during the $16^{\text {th }}$ century. Having been segregated and oppressed by your government for your beliefs, an individual such as this may have decided to come to America, an unexplored world of adventures and opportunities. The Europeans that first came to America implemented their own views of what was right upon the Native Americans, forcing them into submission. Over the years following the arrival of the Europeans, the Native American population slowly declined in numbers, having been overrun by the vast amount of new settlers, that seemed to multiply exponentially.

The situation I have just explained to you is more than one of just human geography. It is the story of an everyday event that is happening in our rangelands, and throughout much of the nation. The Eastern Red Cedar, like the Europeans, has been under extreme conditions of isolation for its negative effects on the surrounding environment.

This juniper, although the name implies cedar, has increased in population more rapidly than any other woody plant on the central grasslands today. It was first used in the 1930s as a windbreak. Even though the red cedar is native to Oklahoma, it is not indigenous to many of the areas it now grows. When the first USDA Soil Conservation Service survey was done to see the extent of the red cedar in 1950 , this individual species had invaded more than 1.5 million acres in the state of Oklahoma alone. It has increased in distribution nearly $80 \%$ during a nine year period, from 1985 to 1994 , and now occupies almost $50 \%$ of the native grassland in Oklahoma.

The growth rate is about $4 \%$, which may appear minimal at first, but equates to a doubling of acreage every 18 years. By 2013, it is predicted that over 8 million acres will be covered with 250 trees or more per acre, which constitutes a red cedar forest.

Once the forest are developed, their effect on the rangeland economy is mind boggling. These trees can cut the carrying capacity and stocking rate for cattle down by at least $70 \%$ in a short time frame, sometimes as little as 10 to 15 years. The broad base of the juniper, which can easily exceed 15 feet, chokes out a large number of desirable vegetation in the area equal to the percentage of canopy. Besides affecting the grazing area of cattle, the red cedar also influences another financial avenue; that of timber and paper mills.

Several companies are now starting to take advantage of the invasive cedar, which overruns the forests that they harvest from, and offer it as a product, along with the trees that provide for their main revenue. Oklahoma has almost 5 million acres of timberland. Although located generally in the eastern past of the state, lumber still provides for a major percentage of income for Oklahomans.

\section{Habitat Being Overrun}

Other vegetation besides that of profitable timber has also been affected, such as that used by native birds. Bird species, including those of grassland game birds, such as quail, have declined in large quantities, doing so accordingly with an increase of non-native woody cover as little as $3 \%$. This was first noticed in a study by Oklahoma State University. The impacts of these trees on avian life had never been studied before and researchers found the results devastating. It was found that most species of the grassland birds share an aversion to widespread woody vegetation, although certain types of woody plants, such as plums and sand sage are critical to their survival.

In fact, one or two trees per acre impact grassland bird populations due to their use by predatory birds for perch sites, just as hunters use elevated tree stands. Birds, depending upon the species, base their selection of habitat on visual clues from the structure that the ecosystem provides for its specific needs. The invasion of excess 
woody plants onto grasslands reduce the availability of desirable habitat for avian life.

Landowners who profit from hunting leases are finding it more and more difficult to sustain positive bird population in areas that contain Red Cedar forest.

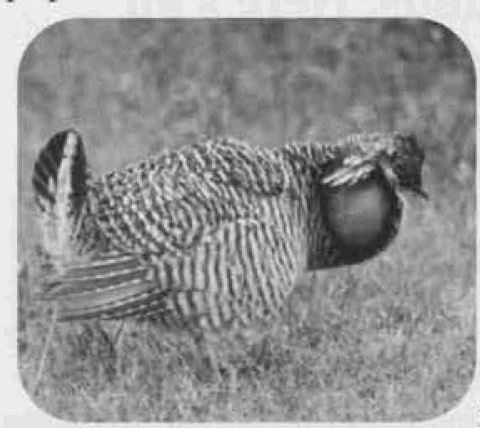
Another bird habitat that is being devastated by this juniper is that of the Greater and Lesser Prairie Chickens. These birds, a species of concern, rely on other native vegetation that is a victim of the rapid spreading cedar. In an effort to counter the declining numbers of the prairie chicken, the USDA has designated certain prairie chicken habitat recovery zones, determined through range surveys conducted by the United States Fish and Wildlife service in cooperation with local ranchers. The recovery process is being carried out and funded through the EQIP, or Environmental Quality Incentive Program, carried out under the direction of the National Resource Conservation Service.

In conjunction with suffocating weaker plant species in beneficial wildlife habitats, the Eastern Red Cedar also poses a threat to deciduous vegetation. One way it endangers plants, such as apple trees, is through a disease known as cedar-apple rust. A hard brown growth forms on branches that vary in size from a grape to a walnut. Spores released during the spring that are lucky enough to land on apple trees cause brown spots to appear on fruit and leaves.

Another pest that inhabits the red cedar is the bagworm. Although it poses little threat to this juniper, once it develops on deciduous vegetation, it strips the foliage, causing branch dieback or death of the tree. These are two of the more common problems associated with this tree.

\section{Tools For Control}

In view of the fact that the problem of the Red Cedar was not discovered until the 1950 , it got the jump on the technology and techniques used to get rid of it. Today, we have the technology and know of several ways of removing the trees, which include use of machinery, pesticide, targeted burning, or as an integrated approach, using several of the practices in combination with on another.

The use of machinery includes the use of a special saw attachment that hooks onto a front end loader or skid stop loader that was designed to eliminate trees in formerly inaccessible areas. This helps in areas of extremely dense forage and along gullies and bottoms. The drawbacks of this operation are numerous. The machinery leaves bare ground, mainly from the tire tracks, but also from where the tree suffocated plant life, which are prone to erosion. Although the trees are eliminated from the site, their seeds remain in the area and can germinate to produce more trees, sometimes increasing pre-treatment levels within 10 to 15 years.

Herbicides are another avenue of pursuit which also offer a temporary removal of the trees. Herbicides can run off into streams harming beneficial plants in the area, as well as polluting groundwater.

That leaves only one favorable option: targeted burning. Fire was the keystone process in the development of the central grasslands in America, including much of Oklahoma. Of the three options, this is the one that most environmentalist find the most effective and holds the least drawbacks.

Using the same principles as open rangeland burning, targeted burning of cedars clears out growth, both dead and undesirable, and allows other plants to sprout in the newly opened area. Because of their extremely thin bark, the cedars are extremely sensitive to fire.

The Natural Resource Conservation Service and local Soil and Water Conservation Districts are vital in implementing this task though. They can offer technical assistance to develop a timeline for prime burning conditions to individuals wishing to burn trees. Many districts have equipment and the NRCS can provide range specialists on-site for technical assistance if necessary.

To enhance the roosting areas of turkeys that were affected by dense vegetation and lack of open treetops, the National Wild Turkey Federation has donated a fourwheeler and burn equipment to a

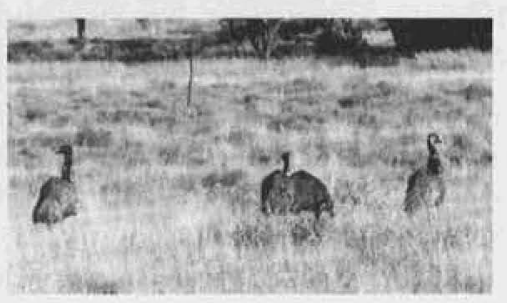

Washita Conservation District. The equipment offered to my family included a drip torch that had been used successfully on previous burning occasions and various other accessories.

My family wanted to experiment with other possible ways that an ordinary farm family could increase the productivity by simply ridding the land of a nuisance. Most ranchers in northwest Oklahoma own or have access to a simple propane torch. By spraying trees down with diesel using a small, inexpensive pump sprayer, the trees can reach the temperature once lit at which they will not grow back, and cannot germinate further. To make the propane torch more portable, we also constructed a simple cart from bicycle wheels and scrap metal. We followed the burning up by cutting off the top 
stalks of the trees, therefore further eliminating any possibility that the tree may come back. The one chink in the armor of an Eastern Red Cedar is that it does not resprout. This proved highly successful and was cost effective when related to the financial impact these trees have on the economy.

The challenge and adventure of a new life, free from prejudice and unjust pressure from above power, is all that the red cedar seeks. However, by seeking it through its aggressive movements, the Eastern Red Cedar is quickly causing a shift between the native inhabitants and this unwelcome invader throughout the state of Oklahoma.
A Spanish philosopher by the name of George Santayana once said, "Those who do not remember the past are condemned to repeat it." Having learned from past experiences, and now having the proper equipment and procedures, the Eastern Red Cedar may be stopped in its tracks and effectively controlled. We have the technology. By looking upon the past, and taking advantage of the present, the natives will not forced into submission and overrun.

This was the second place paper in the student High School Youth Forum competition at the Annual SRM Meeting held in Kansas City in Feb. 2002.

\section{From the Manufacturers of the FLEX II No-Till Grass Drill, Seed Slinger Broadcaster, and Trillion Culti-pack Drop Seeder}

trUaX Introduces a true Heavy Duty Rangeland Planter iougon íciere

- Variable penetration weight to planting units

- Two foot vertical travel on each planting unit

- Four foot carrying wheels
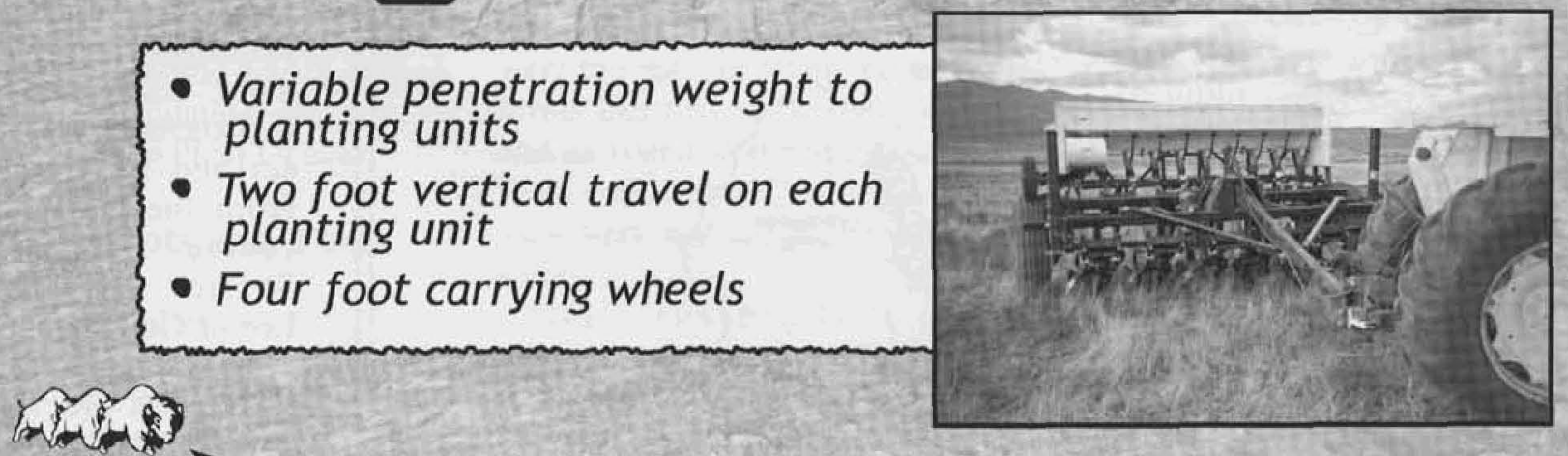

$\widehat{\text { truax COMPANY, INC }}$

4821 Xernes Ave North

Minneapolis, MN 55430 